\title{
PENYUSUNAN DAN IMPLEMENTASI SISTEM PELAYANAN PUBLIK SURAT PENGANTAR RT/ RW ONLINE UNTUK MEWUJUDKAN SEMARANG "SMART CITY"
}

\author{
Muhammad Khafid, Agus Wahyudin \\ Universitas Negeri Semarang \\ Email: muh_khafid@mail.unnes.ac.id
}

\begin{abstract}
Every citizen expects that $R T / R W$ cover letter service can be obtained quickly and accurately. However, the expectation of public services such as introducing $R T$ / $R W$ letters sometimes can not be realized. Often the handling of $R T / R W$ cover letters takes days. The purpose of this community service activity is to improve the quality of public service in the form of introductory letter service of $R T$ / $R W$ for the people in need. Specific targets of community service are: (1) establishment of public service system of $R T / R W$ introduction letter online, and (2) implementation of public service system of $R T / R W$ introduction letter online. Based on the results of community service activities, it is concluded that the RT RW online introduction letter application system is one of the alternative solutions for effective citizen administration services, since this system can overcome the difficulties of citizens in obtaining administrative services indefinitely dimensional space and time. The residents welcomed the existence of this $R T R W$ online introduction letter application system, especially for residents of immigrant residents (residents of residential complex). However, for the original villagers, the existence of this system has not been so needed. The majority of the original villagers will not use this online system. Based on feedback on the ease of use of the system and the attractive appearance of this system, it is realized that the system is still a lot of shortcomings, so that future improvements are still needed.
\end{abstract}

Keyword: Public Service, Semarang Smart City, Introduction Letter RT / RW

\begin{abstract}
Abstrak. Setiap warga masyarakat mengharapkan pelayanan surat pengantar RT/RW dapat diperoleh secara cepat dan tepat. Namun demikian, harapan pelayanan publik surat pengantar RT/RW yang demikian terkadang tidak bisa terwujud. Seringkali pengurusan surat pengantar RT/RW memakan waktu berharihari. Tujuan dari kegiatan pengabdian masyarakat ini adalah meningkatkan kualitas pelayanan publik berupa pelayanan surat pengantar RT/RW bagi warga masyarakat yang membutuhkan. Target khusus dari pengabdian kepada masyarakat ini adalah: (1) disusunnya sistem pelayanan publik surat pengantar RT/RW secara online, dan (2) diimplementasikannya sistem pelayanan publik surat pengantar RT/RW secara online. Berdasarkan hasil kegiatan pengabdiam masyarakat, disimpulkan bahwa sistem aplikasi surat pengantar RT RW online merupakan salah satu solusi alternatif pelayanan administrasi warga yang efektif, karena sistem ini bisa mengatasi permasalahan kesulitan warga dalam memperoleh layanan administrasi tanpa batas dimensi ruang dan waktu. Warga menyambut baik keberadaan sistem aplikasi surat pengantar RT RW online ini, terutama bagi warga penduduk pendatang (warga kompleks perumahan). Namun demikian, bagi warga penduduk kampung asli, keberadaan sistem ini belum begitu dibutuhkan. Mayoritas warga penduduk kampung asli belum akan menggunakan sistem online ini. Berdasarkan
\end{abstract}


hasil umpan balik tentang kemudahan penggunaan sistem dan tampilan menarik dari sistem ini, disadari sistem ini masih banyak kekurangan, sehingga penyempurnaan di masa mendatang masih sangat diperlukan.

Kata Kunci: Pelayanan Publik, Semarang Smart City, Surat Pengantar RT/ RT

\section{PENDAHULUAN}

Aparatur pemerintah di semua jenjang mulai dari aparatur Pemerintah di tingkat Pusat, Provinsi, Kota/Kabupaten, Kecamatan, sampai dengan tingkat Desa/Kelurahan berkewajiban memberikan pelayanan publik yang baik kepada warga masyarakat. Di sisi lain, warga masyarakat berhak memperoleh pelayanan publik yang baik dan berkualitas dari pemerintah. Pelayanan publik yang baik, tepat, cepat, ramah, dan menyenangkan adalah harapan semua pihak. Pelayanan publik yang baik akan memberikan dampak bagi kedua belah pihak baik bagi pemerintah selaku pelayan masyarakat, maupun bagi warga masyarakat selaku pengguna layanan. Bagi pemerintah, pelayanan publik yang baik akan meningkatkan kepercayaan warga masyarakat dan persepsi baik terhadap pemerintah. Bagi warga masyarakat, pelayanan publik yang baik akan meningkatkan rasa nyaman, tenteram, sehingga kesejahteraan meningkat.

Pelayanan Publik adalah sebagai setiap kegiatan yang dilakukan oleh pemerintah terhadap sejumlah manusia yang memiliki setiap kegiatan yang menguntungkan dalam suatu kumpulan atau kesatuan, dan menawarkan kepuasan meskipun hasilnya tidak terikat pada suatu produk secara fisik (Sinambela dkk, 2010). Hardiyansyah (2011) mendefinisikan pelayanan publik sebagai kegiatan pemberian jasa baik oleh pemerintah, pihak swasta atas nama pemerintah ataupun pihak swasta kepada masyarakat, dengan atau tanpa pembayaran guna memenuhi kebutuhan dan atau kepentingan masyarakat. Undang-Undang Nomor 25 Tahun 2009 tentang Pelayanan Publik mendefinisikan pelayanan publik sebagai kegiatan atau rangkaian kegiatan dalam rangka pemenuhan kebutuhan pelayanan sesuai dengan peraturan perundang-undangan bagi setiap warga negara dan penduduk atas barang, jasa, dan/atau pelayanan administratif yang disediakan oleh penyelenggara pelayanan publik.

Salah satu jenis pelayanan publik yang langsung bersentuhan dengan kepentingan warga masyarakat sehari-hari adalah pelayanan surat pengantar RT/RW. Berbagai pelayanan administratif baik yang berhubungan dengan pengurusan KTP, pengurusan Kartu Keluarga (KK), pengajuan kredit, dan pelayanan administratif lain yang dikeluarkan oleh Kelurahan selalu mensyaratkan adanya surat pengantar RT/RW setempat. Hal ini bertujuan untuk memastikan bahwa warga masyarakat yang dilayani adalah benarbenar penduduk wilayah $\mathrm{RT} / \mathrm{RW}$ setempat.

Namun demikian, harapan pelayanan publik surat pengantar RT/RW yang demikian terkadang tidak bisa terwujud. Seringkali pengurusan surat pengantar RT/RW memakan waktu berhari-hari. Hal ini merupakan masalah faktual yang seringkali dialami warga masyarakat. Sebagaimana dialami oleh Bapak AF salah satu warga yang tinggal di salah satu kelurahan di Kecamatan Gunungpati Kota Semarang, yang menyatakan sudah satu minggu mengurus 
surat pengantar RT/RW belum selesai karena Ketua RT dan Ketua RW sulit ditemui (Wawancara bulan Februari 2017 dengan Bapak AF). Ketika diidentifikasi, masalah tersebut dapat terjadi karena:

1. Jabatan Ketua RT dan Ketua RW adalah jabatan sosial dengan semangat pengabdian, sehingga tidak memiliki jam kerja pelayanan tertentu. Ketika warga masyarakat mengurus surat pengantar RT/RW pada siang hari, Ketua RT/RW telah beraktivitas sesuai dengan pekerjaannya masing- masing. Hal ini menyebabkan warga masyarakat hanya memiliki kesempatan waktu yang sempit untuk mengurus surat pengantar RT/RW (biasanya pukul 18.30 s.d. 20.30).

2. Waktu pengurusan surat pengantar oleh warga masyarakat yang seringkali tidak sama dengan waktu longgarnya Ketua RT/RW. Saat Ketua RT/RW longgar di rumah, tidak ada warga yang mengurus surat pengantar, namun ketika Ketua RT/RW tidak sedang di rumah karena ada suatu keperluan, ada warga yang mengurus surat pengantar.

3. Beban layanan/beban kerja Ketua RT/RW (utamanya Ketua RW) yang amat berat. Sebagaimana disampaikan oleh Bapak MK salah satu Ketua RW di salah satu kelurahan di Kecamatan Gunungpati Kota Semarang, bahwa wilayah RW pak MK terdiri atas 8 RT. Jika dalam setiap bulan ada warga masyarakat yang mengurus surat pengantar 5 saja setiap RT, maka beban pak MK selaku Ketua RW adalah menandatangani surat pengantar sebanyak 40 buah. Itu artinya setiap malam ada 1 sampai 2 warga masyarakat yang mengurus surat pengantar dalam setiap bulannya. Beban yang amat berat.

Oleh karena itu, diperlukan upayaupaya untuk mengatasi permasalahan di atas. Penyelesaian masalah tersebut diharapkan dapat meningkatkan kualitas pelayanan publik pada umumnya dan sistem pengurusan surat pengantar RT/RW pada khususnya. Peningkatan kualitas pelayanan publik dapat menyebabkan peningkatan kesejateraan dan rasa tenteram warga masyarakat.

Permasalahan umum tentang pelayanan publik surat pengantar RT/RW di atas merupakan masalah faktual yang dirasakan hampir seluruh warga masyarakat di mana pun. Kelurahan Kalisegoro sebagai salah satu kelurahan di Kecamatan Gunungpati Kota Semarang juga menghadapi masalah yang sama dengan masalah yang diuraikan di atas. Sebagai kelurahan sub urban, Kelurahan Kalisegoro memiliki karakteristik sebagai berikut:

1. Selain dihuni penduduk asli yang mayoritas bekerja sebagai petani dan pedagang, juga dihuni penduduk pendatang dengan tingkat pendidikan, profesi/pekerjaan, latar belakang sosial budaya yang berbeda-beda.

2. Terdapat komplek perumahan sebagai pemukiman baru dengan jumlah penduduk di kompleks perumahan hampir $40 \%$ dari total penduduk kelurahan (hasil wawancara dengan Lurah Kalisegoro, Februari 2017).

Karakteristik kelurahan yang demikian, sebagai warga masyarakat maju dan modern, tentu mengharapkan pelayanan publik yang berkualitas dengan indikator baik, cepat, dan tepat. Pelayanan yang cepat dan tepat sudah menjadi harapan warga masyarakat Kelurahan Kalisegoro. Oleh karena itu diperlukan solusi pelayanan publik pengurusan surat pengantar RT/RW yang inovatif berbasis teknologi untuk mengatasi permasalahan tersebut. Di samping itu, harapan Pemerintah Kota Semarang untuk mewujudkan Kota Semarang sebagai "Smart 
menjadipelayanantuntutanpublikyang cepat, tepat, modern berbasis teknologi informasi. Berdasarkan uraian di atas, maka "Penyusunan dan Implementasi Sistem Pelayanan Publik Surat Pengantar RT/RW secara online untuk Mewujudkan Semarang "Smart City" menjadi penting, rasional, dan amat mendesak untuk dilakukan.

Berdasarkan masalah dan analisis situasi sebagaimana dipaparkan pada Bab 1, maka diperlukan solusi pelayanan publik pengurusan surat pengantar RT/RW yang inovatif berbasis teknologi untuk mengatasi permasalahan tersebut. Solusi pelayanan pengurusan surat pengantar RT/RW tersebut setidaknya memiliki karakteristik sebagai berikut:

1 Pelayanan Cepat. Pelayanan publik yang cepat merupakan tuntutan dan harapan dari masyarakat modern. Penghargaan yang semakin tinggi terhadap waktu menjadikan pola hidup yang efisien, sederhana, dan tidak berbelit-belit. Birokrasi yang panjang dalam pengurusan surat pengantar RT/RW harus dapat direformasi menjadi birokrasi yang sederhana namun tetap aman sehingga tidak disalahgunakan oleh oknum warga masyarakat yang tidak bertanggung jawab.

2 Pelayanan Tepat. Pelayanan publik yang hanya butuh cepat, tetapi juga harus tepat. Pelayanan yang cepat namun ditemukan beberapa kesalahan yang menyebabkan tidak sahnya sebuah dokumen dan mengharuskan mengulangi lagi menjadikan pelayanan yang tidak efisien.

3 Pelayanan yang tanpa batas dimensi ruang dan waktu. Jabatan Ketua RT dan Ketua RW yang tidak memiliki jam kerja pelayanan khusus pada jamjam tertentu membutuhkan inovasi sistem pelayanan publik yang dapat diakses kapan pun, di mana pun, dan dalam keadaan apa pun. Pelayanan yang tidak mengharuskan terjadi tatap muka, dapat dilakukan kapan saja, dan ketika Ketua RT/RW di kantor/tempat aktivitasnya masing-masing adalah solusi yang diharapkan dapat mengatasi permasalahan di atas.

\section{METODE}

\section{Kerangka Pemecahan Masalah}

Solusi yang ditawarkan untuk mengatasi permasalahan yang muncul seputar pelayanan publik pengurusan surat pengantar RT/RW adalah Penyusunan dan Implementasi Sistem Pelayanan Publik Surat Pengantar RT/RW secara online. Kegiatan ini dilaksanakan melalui tiga tahapan kegiatan pelaksanaan, yaitu:

1. Penyusunan desain sistem pelayanan publik surat pengantar RT/RW secara online. Tahapan ini dilakukan oleh tim pengabdi. Tim pengabdi memiliki keahlian di bidang teknologi informasi sehingga dapat menyusun desain sistem pelayanan publik surat pengantar RT/RW secara online yang dimaksud.

2. Penyiapan dan penataan kesiapan jaringan, hardware, dan software untuk implementasi sistem. Tahapan ini dilaksanakan secara bekerja sama dengan instansi mitra yaitu Pemerintah Kelurahan Kalisegoro. Pemerintah Kelurahan Kalisegoro diharapkan bersedia menyediakan jaringan internet di Kantor Kelurahan dan seperangkat peralatan komputer yang terkoneksi dengan jaringan internet. Jaringan internet di masing-masing warga masyarakat diasumsikan telah tersedia melalui smartphone yang dimiliki warga masyarakat.

3. Pelatihan penggunaan sistem pelayanan publik surat pengantar RT/RW secara online sebagai uji coba. Pelatihan penggunaan sistem ini 
dilakukan melalui pembagian empat tingkatan, yaitu:

a. Warga masyarakat (perwakilan warga masyarakat), sebagai pemohon yang mengajukan pelayanan surat pengantar RT/RW.

b. Ketua RT sebagai validator 1 , yang bertugas melakukan validasi kebenaran data yang diisikan oleh pemohon.

c. Ketua RW sebagai validator 2 .

d. Lurah/Sekretaris Lurah yang akan

Warga masyarakat bemak memoeroler Iayanan oubik yang bek dan berua as. Setao warga masyarakat mengharaokar layanan sura: pengartar. RTiRW daos: o oero th secara ceos: dan tood: mencetak surat pengantar RT/RW dan dapat dipergunakan untuk berbagai keperluan.

4. Implementasi sistem pelayanan publik surat pengantar RT/RW secara online pada salah satu RW di Kelurahan Kalisegoro.

Secara ringkas, kerangka pemecahan masalah trsebut dapat diilustrasikan dalam Gambar 1.
Serngkaí pengunsan surat pengartar RTIRW memakan waiks berhan-han. $\mathrm{Hal}$ ini meruoakan masalah faktual yang serngkai dalami varga masyarakat.

Penyebab:

Jabatan Keua RT dan Ketua RW adalah jabatan sosial yang tdak memilk jam kera layanan terenty

Waku pengurusan surat pengartar oleh warga masyarakat yang senngkal tdak sama dengan wake longgamya Kesa RT/RW.

Beban layananbeban kena Keua RT/RW (utamanya Keua RW) yang amat berat.

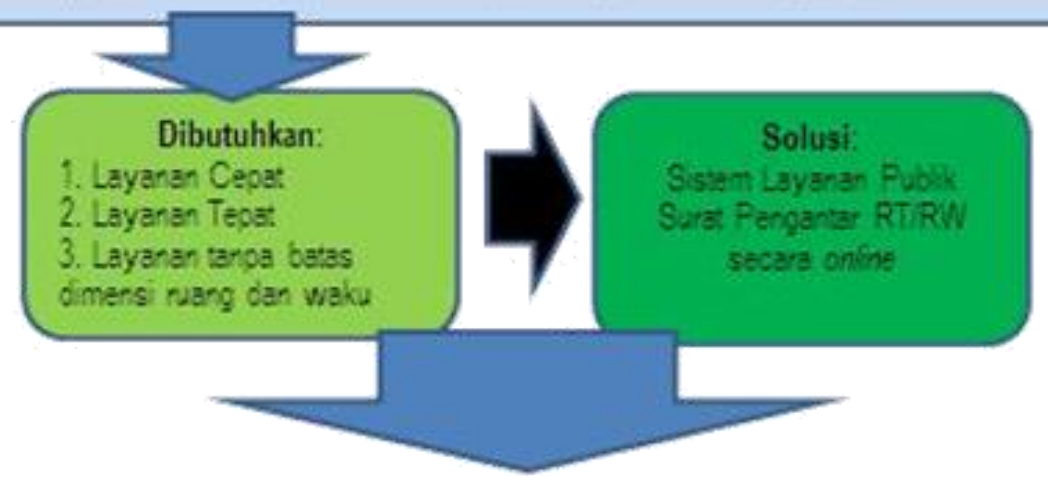

Penyusunan desain sistem

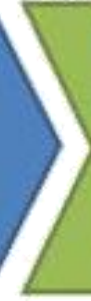

Pelatihan penggunaan sistem:

1. Warga masyarakat

Penyiapan dan penataan jaringan, hardware, soltware

2. Ketua RT

3. Ketua RW

4. Lurah/Sekretaris

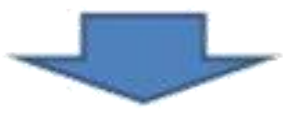

\section{hardware, solware}

Gambar 1. Kerangka Pemecahan Masalah 


\section{HASIL DAN PEMBAHASAN}

Untuk memenuhi harapan pelayanan publik sesuai dengan karakteristik di atas, maka solusi yang ditawarkan adalah:

Penyusunan dan Implementasi Sistem Pelayanan Publik Surat Pengantar RT/RW secara online. Solusi berupa sistem pelayanan publik berupa surat pengantar RT/RW ini memiliki

spesifikasi atau deskripsi singkat sebagai berikut:

1. Pemerintah tingkat kelurahan menyediakan laman sistem Surat Pengantar RT/RW berbasis online yang dapat diakses oleh: (1) warga masyarakat sebagai user, (2) Ketua RT sebagai validator 1, (3) Ketua RW sebagai validator 2, dan (4) Lurah/Sekretaris Lurah.

2. Warga masyarakat yang akan melakukan pengurusan surat pengantar RT/RW masuk laman tersebut dan mengisi data yang dibutuhkan pada menu tertentu. Jika database warga sudah ada di dalam sistem, maka warga tinggal mengisi tujuan/keperluan pengurusan surat pengantar RT/RW.

3. Data mengenai warga masyarakat yang melakukan pengurusan surat pengantar akan masuk ke akun Ketua RT pada menu tertentu selaku validator 1. Ketua RT bisa melakukan validasi atau menunda validasi dengan memberikan pesan tertentu. Penundaan validasi ini dapat disebabkan karena warga tersebut belum menunaikan kewajiban iuran atau kewajiban lain yang telah disepakati di masing-masing RT.

4. Pada saat Ketua RT telah melakukan validasi, maka di akun warga masyarakat yang mengajukan surat pengantar akan terlihat indikator tervalidasi 1.

5. Data mengenai warga masyarakat yang melakukan pengurusan surat pengantar dan telah tervalidasi $\mathbf{1}$, akan masuk ke akun Ketua RW pada menu tertentu selaku validator 2. Ketua RW bisa melakukan validasi atau menunda validasi dengan memberikan pesan tertentu. Penundaan validasi ini dapat disebabkan karena warga tersebut atau wilayah RT tersebut belum menunaikan kewajiban di tingkat RW yang telah disepakati di masingmasing RW.

6. Pada saat Ketua RW telah melakukan validasi, maka di akun warga masyarakat yang mengajukan surat pengantar akan terlihat indikator tervalidasi 2. Warga masyarakat bisa langsung menuju Kantor Kelurahan untuk menunggu proses pencetakan surat di Kantor Kelurahan.

7. Data mengenai warga masyarakat yang melakukan pengurusan surat pengantar dan telah tervalidasi 2 , akan masuk ke akun Lurah/Sekretaris Lurah. Surat siap untuk dilakukan pencetakan surat dan selanjutnya diserahkan kepada warga masyarakat yang mengajukan surat

Keunggulan dari sistem pelayanan publik surat pengantar RT/ RW secara online sebagai sebuah solusi dapat diidentifikasi sebagai berikut:

1. Pelayanan publik surat pengantar RT/RW dapat dilakukan dengan cepat dan tepat, sehingga birokrasi dapat direformasi menjadi birokrasi yang sederhana.

2. Ketua RT dan Ketua RW dapat melayani warga masyarakat dengan baik tanpa batas waktu, ruang, tatap muka, sehingga tidak mengganggu aktivitas pekerjaan masing-masing maupun waktu berkumpul dengan keluarga.

3. Pelayanan publik surat pengantar $\mathrm{RT} / \mathrm{RW}$ berbasis online dengan memanfaatkan teknologi informasi 
dapat menjadi branding dan mendukung Pemerintah Kota Semarang "SmartCity".

4. Pelayanan publik surat pengantar RT/RW berbasis online dapat menjadi pilar kesuksesan Kelurahan Kalisegoro sebagai kelurahan tematik tahun 2017 dengan tema

"Kalisegoroona".Dengansejutapelayan ansuratdanyapes pengantar RT/RW berbasis online yang modern, menjadikan Kelurahan Kalisegoro layak dikunjungi sebagai destinasi wisata maupun studi banding dari instansi pemerintah dari berbagai daerah.

5. Mengangkat citra Universitas Negeri Semarang sebagai perguruan tinggi yang telah memiliki branding sebagai perguruan tinggi yang unggul di bidang teknologi informasi untuk resource sharing bagi pengembangan wilayah sekitar kampus. Jika program ini berhasil maka diprediksi dapat digunakan dan diimplementasikan bagi pelayanan pengurusan surat pengantar RT/RW bagi seluruh warga masyarakat di Pemerintah Kota Semarang.

Namun demikian, disadari bahwa sebagai bentuk pelayanan modern dan baru, tentu tetap memiliki kelemahan atau hambatan. Kelemahan atau hambatan yang diprediksi muncul dari implementasi sistem pelayanan publik surat pengantar RT/RW secara online ini adalah:

1. Tidak setiap warga dapat menggunakan teknologi informasi. Kelemahan ini dapat diatasi dengan melakukan pelatihan oleh tim pengabdi maupun oleh warga lain yang telah mampu menggunakan. Oleh karena itu, sebagai langkah antisipasi untuk meminimalkan kelemahan atau hambatan tersebut, maka sistem aplikasi harus dibuat dan didesain sesederhana mungkin, dan semudah mungkin untuk digunakan (easy to use).

2. Pelayanan publik surat pengantar RT/RW berbasis online akan mengurangi interaksi sosial warga masyarakat dengan Ketua RT dan Ketua RW. Kelemahan atau hambatan ini dapat diatasi dengan meningkatkan kualitas interaksi sosia melalui pertemuan rutin bulanan atau bentuk lain. Pelayanan konvensional yang selama ini berjalan pun tidak menjamin terciptanya interaksi sosial warga masyarakat dengan Ketua RT dan Ketua RW. Hal ini karena beberapa warga masyarakat mengurus surat pengantar dengan cara meminta bantuan kepada anaknya, pembantu rumah tangga, atau satpam perumahan.

Kegiatan pengabdian kepada masyarakat ini terdiri atas dua tahap kegiatan besar, yaitu:

1. Penyusunan sistem aplikasi Surat Pengantar RT/RW secara online.

2. Implementasi sistem aplikasi Surat Pengantar RT/RW secara online.

Wilayah RW 3 Kelurahan Kalisegoro memiliki 8 wilayah RT. Wilayah tersebut dapat dikelompokkan menjadi dua tipe warga yaitu, warga penduduk asli kampung Kalisegoro yang terdiri atas RT 1, 2, dan 3; dan warga penduduk pendatang yang tinggal di Perumahan Griya Sekargading yang terdiri atas RT 4, 5, 6, 7, dan 8 . Implementasi sistem aplikasi surat pengantar RT RW online pada tahap I ini dilakukan di dua RT, yaitu RT 1 dan RT 5. Pemilihan kedua RT tersebut di anggap cukup untuk mewakili tipe warga dilihat dari sisi tingkat pendidikan, sosial budaya, kesibukan, dan karakteristik tertentu.

Kegiatan implementasi sistem aplikasi surat pengantar RT RW online dilakukan dengan tahap sebagai berikut:

1. Penyajian materi sistem aplikasi surat 
pengantar RT RW online oleh tim pengabdi kepada warga RT 1 dan RT 5. Penyajian materi diselenggarakan bersamaan dengan kegiatan pertemuan warga di wilayah RT tersebut. Penyajian materi kepada warga RT 1 diselenggarakan pada hari Sabtu, 30 September 2017. Pertemuan di RT 1 dihadiri 48 warga. Penyajian materi kepada warga RT 5 diselenggarakan pada hari Minggu, 8 Oktober 2017. Pertemuan di RT 5 ini dihadiri 36 warga.

2. Pembuatan dan pendaftaran akun operator tingkat RT yang dilakukan oleh sekretaris RT. Di samping itu, dilakukan input data base warga (dilakukan secara sampel), dan akan dilanjutkan oleh Pengurus RT masingmasing.

3. Uji coba sistem aplikasi surat pengantar RT RW online untuk beberapa warga.

4. Melakukan penelitian sederhana untuk mengetahui umpan balik warga mengenai keberadaan sistem aplikasi surat pengantar RT RW online ini. Beberapa pertanyaan yang diberikan kepada warga terdiri atas:

a. Apakah Saudara menyukai sistem aplikasi surat pengantar RT RW online yang disusun oleh tim pengabdi?

\begin{tabular}{clcccc}
\hline No & \multicolumn{1}{c}{ Pertanyaan } & Warga RT 1 & \multicolumn{2}{c}{ Warga RT 5 } \\
\hline 1 & Apakah Saudara menyukai sistem aplikasi & 48 & 0 & 36 & 0 \\
& surat pengantar RT RW online yang & $100 \%$ & $0 \%$ & $100 \%$ & $0 \%$ \\
& disusun oleh tim pengabdi? & Suka & Tidak & Suka & Tidak \\
2 & $\begin{array}{l}\text { Apakah Saudara setuju jika sistem aplikasi } \\
\text { suratpengantarRTRWonline }\end{array}$ & 44 & 4 & 19 & 17 \\
& $\begin{array}{l}\text { diberlakukan untuk menambah alternatif } \\
\text { layanan pengurusan surat pengantar RT }\end{array}$ & Setuju & $8 \%$ & $53 \%$ & $47 \%$ \\
$\quad$ RW? & & & & \\
Ridak & Setuju & Tidak \\
Apakah Saudara telah memahami system & 38 & 10 & 6 & 30 \\
$\quad \begin{array}{l}\text { aplikasi surat pengantar RT RW online } \\
\text { yang dipaparkan oleh tim pengabdi? }\end{array}$ & $79 \%$ & $21 \%$ & $17 \%$ & $83 \%$ \\
Apakah Saudara akan menggunakan & Ya & Tidak & Ya & Tidak \\
\end{tabular}

b. Apakah Saudara setuju jika sistem aplikasi surat pengantar RT RW online diberlakukan untuk menambah alternatif layanan pengurusan surat pengantar RT RW?

c. Apakah Saudara telah memahami sistem aplikasi surat pengantar RT RW online yang dipaparkan oleh tim pengabdi?

d. Apakah Saudara akan menggunakan sistem aplikasi surat pengantar RT RW online pada saat mengurus surat pengantar RT RW?

e. Apakah sistem aplikasi surat pengantar RT RW online yang disusun oleh tim pengabdi mudah untuk digunakan?

f. Apakah sistem aplikasi surat pengantar RT RW online yang disusun oleh tim pengabdi memiliki tampilan yang menarik?

Berikut ini disajikan hasil dari jawaban warga atas pertanyaan yang diberikan: 


$\begin{array}{llclll}\text { sistem aplikasi surat pengantar RT RW } & 96 \% & 4 \% & 17 \% & 83 \% \\ \text { online pada saat mengurus surat } & \text { Ya } & \text { Tidak } & \text { Ya } & \text { Tidak } \\ \text { pengantar RT RW? } & & & & \end{array}$

5 Apakah sistem aplikasi surat pengantar RT RW online yang disusun oleh tim pengabdi mudah untuk digunakan?

6 Apakah sistem aplikasi surat pengantar RT RW online yang disusun oleh tim pengabdi memiliki tampilan yang menarik?

Berdasarkan jawaban warga terhadap beberapa pertanyaan yang diajukan secara wawancara oleh tim pengabdi dapat diketahui bahwa secara umum warga menyukai keberadaan sistem aplikasi surat pengantar RT RW online ini. Sebanyak $100 \%$ warga menjawab menyukai sistem aplikasi surat pengantar RT RW online. Ketika ditanya tentang persetujuannya jika sistem aplikasi surat pengantar RT RW online ini diterapkan, terdapat perbedaan jawaban yang menyolok antara warga RT 1 yang mewakili tipe warga penduduk kampung, dengan warga RT 5 yang mewakili tipe warga penduduk pendatang yang lebih modern. Sebanyak 92\% warga RT 5 setuju jika sistem aplikasi surat pengantar RT RW online ini diterapkan. Namun demikian warga RT 1 yang setuju jika sistem aplikasi surat pengantar RT RW online ini diterapkan hanya $53 \%$.

Tingkat pemahaman warga setelah dilakukan penyajian materi tentang sistem aplikasi surat pengantar RT RW online juga berbeda antara warga RT 1 dan RT 5. Sebanyak $79 \%$ warga RT 5 menyatakan telah memahami materi yang disajikan, sedangkan warga RT 1 yang menyatakan paham atas materi sistem aplikasi surat pengantar RT RW online hanyak 17\%. Sebanyak 96\% warga RT 5 akan menggunakan sistem aplikasi surat pengantar RT RW online pada saat membutuhkan layanan pengantar RT RW, sedangkan bagi warga RT 1 yang akan menggunakan

$\begin{array}{cc}21 & 27 \\ 44 \% & 56 \% \\ \mathrm{Ya} & \text { Tidak } \\ 26 & 22 \\ 54 \% & 46 \% \\ \mathrm{Ya} & \text { Tidak }\end{array}$

sistem aplikasi surat pengantar RT RW online ini hanya $17 \%$.

Khusus pertanyaan tentang fitur kemudahaan dan tampilan yang menarik, maka hasil yang dapat disajikan hanya untuk warga RT 5. Untuk warga RT 1, tim pengabdi memandang pertanyaan ini belum relevan untuk dapat dijawab oleh warga RT 1. Bagi warga RT 5 memandang bahwa sistem aplikasi surat pengantar RT RW online masih relatif sulit untuk digunakan. Mereka yang menyatakan bahwa sistem ini mudah digunakan baru sebesar 44\%. Di tinjau dari tampilan sistem, sebanyak 54\% menyatakan menarik, dan sisanya sebesar $46 \%$ menyatakan tidak menarik. Berdasarkan hasil ini maka pengembangan sistem aplikasi surat pengantar RT RW online masih diperlukan di masa mendatang.

\section{SIMPULAN}

\section{Simpulan}

Berdasarkan hasil pengabdian masyarakat yang telah dipaparkan di atas, maka dapat disimpulkan beberapa hal sebagai berikut:

1. Sistem aplikasi surat pengantar RT RW online yang disusun oleh tim pengabdi merupakan salah satu solusi alternatif pemberian pelayanan administrasi warga yang efektif, karena sistem ini bisa mengatasi beberapa permasalahan kesulitan warga dalam memperoleh layanan administrasi surat pengantar RT RW 
yang cepat dan tanpa batas dari pengantar.

dimensi ruang dan waktu.

2. Warga menyambut baik keberadaan sistem aplikasi surat pengantar RT RW online ini, terutama bagi warga penduduk pendatang (warga kompleks perumahan), sangat antusias dan akan menggunakan sistem ini pada saat mengurus surat pengatar RT RW. Namun demikian, bagi warga penduduk kampung asli, keberadaan sistem ini belum begitu dibutuhkan. Mayoritas warga penduduk kampung asli belum akan menggunakan sistem online ini.

3. Berdasarkan hasil umpan balik tentang kemudahan penggunaan sistem dan tampilan menarik dari sistem ini, disadari sistem ini masih banyak kekurangan, sehingga penyempurnaan di masa mendatang masih sangat diperlukan.

\section{Saran}

\section{DAFTAR PUSTAKA}

Abidin, S. Z. 2016. Kebijaan Publik. Salemba Empat.

http://m.semarangpos.com/2016/11/30/se marang-smart-city-beginilahkonsep-pemkot-772878

Sinambela, L.P. 2010. Reformasi Pelayanan Publik. Jakarta. PT. Bumi Aksara.

Syafri, W. 2012. Studi Tentang Administrasi Publik 1. Jakarta. Erlangga.

Topatimasang, R., Fakih, M., dan Rahardjo, T. 2016. Mengubah Kebijakan Publik: Panduan Pelatihan Advokasi. Diandra Primamitra.

Undang-Undang Nomor 25 Tahun 2009 tentang Pelayanan Publik.

Berdasarkan simpulan, agar sistem yang telah dibangun ini dapat diterapkan dengan baik, maka disarankan beberapa hal sebagai berikut:

1. Kepada warga agar segera melakukan input data warga sebagai data base kependudukan di lingkungan RT masing-masing. Warga yang telah lengkap mengisi data base, maka pada saat akan membutuhkan surat pengantar RT RW cukup memasukkan Nomor Induk Kependudukan saja, sehingga proses input data menjadi sangat cepat.

2. Kepada sekretaris RT selaku petugas operator, untuk dapat melakukan update data secara berkelanjutan.

3. Kepada ketua RT dan ketua RW, dimohon secara rutin setiap hari melakukan pengecekan menu permintaan surat pengantar agar selalu dapat melakukan monitor warga yang mengajukan permohonan surat 